\title{
Derleme/Review \\ Köfte Üretiminde Kullanılan Bitkisel Katkıların Üründe Oksidasyon Gelişimi, Mikrobiyolojik ve Duyusal Özellikler ile Heterosiklik Amin (HCA) Oluşumu Üzerine Etkileri
}

\author{
Gülen YILDIZ TURP*, Sezen KALYONCU, İlkin YÜCEL ŞENGÜN \\ Ege Üniversitesi, Mühendislik Fakültesi, Gıda Mühendisliği Bölümü, Bornova, İzmir 35100, Türkiye \\ *e-posta: gulen.yildiz.turp@ege.edu.tr
}

Öz: Et ve et ürünlerinin kalitesini etkileyen ve raf ömrünü azaltan önemli etkenlerin başında oksidasyon ve mikrobiyal gelişim gelmektedir. Üründe meydana gelen oksidasyon lezzet, tekstür ve renkte bozulmalara neden olmakta, sağlığa zararlı bileşenler açığa çıkabilmektedir. Mikrobiyal gelişim gıdada bozulmalara neden olurken patojen mikroorganizmaların gelişimi durumunda gıda kaynaklı hastalıklar da meydana gelebilmektedir. Et ve et ürünlerinde oluşan bu değişimleri engellemek üzere antioksidan ve antimikrobiyal katkılar yaygın olarak kullanılmaktadır. Son yıllarda sağlık ile ilgili endişelerden dolayı et ürünlerinde sentetik katkılar yerine doğal katkıların, özellikle de bitkisel katkıların kullanımına yönelik çalışmalar önemli bir artış göstermiştir. Köfte tipi et ürünlerinde kullanılan bazı bitkisel katkıların mutajenkanserojen olarak kabul edilen ve yüksek sıcaklıklarda pişirilen et ürünlerinde oluşan heterosiklik aminler (HCA) üzerinde de önleyici bir etki gösterdiği belirlenmiştir. Farklı araştırmacılar tarafından yapılan çalışmalarda, köftede kullanılan biberiye, kekik, yeşil çay, enginar, üzüm çekirdeği, zeytin, karanfil gibi doğal katkıların oksidasyon sonucu oluşan kalite kayıplarını azalttığı ve mikrobiyal kaliteyi olumlu yönde etkilediği belirlenmiştir. Bu çalışmada, bitkisel kaynaklı antioksidan ve antimikrobiyal katkıların kullanımının köftenin kimyasal, mikrobiyolojik ve duyusal özellikleri ile Heterosiklik amin (HCA) oluşumu üzerine etkilerinin incelendiği çalışmalar derlenerek sunulmuştur.

Anahtar kelimeler: Antimikrobiyal, Antioksidan, Bitkisel katkı, HCA, Köfte

\section{The Effects of Plant Additives Used in Meatball Production on the Development of Oxidation, Microbiological and Sensory Characteristics and Heterocyclic Amine (HCA) Formation}

\begin{abstract}
Oxidation and microbial growth are the most important factors affecting the quality and shelf life of meat and meat products. The oxidation occur in the product induces taste, texture and color deteriorations as well as generation of harmful components to health. Microbial growth causes food spoilage while food-borne diseases can occur when pathogenic microorganisms grow in the product. Antioxidant and antimicrobial additives are widely used to prevent these changes in meat and meat products. Due to health concerns in recent years, there has been a significant increase in the use of natural additives, especially plant additives, instead of synthetic additives in meat products. It has been determined that some plant additives used in meatball type meat products also have a preventive effect on the formation of heterocyclic amines (HCA) that considered as mutagenic-carcinogenic compounds formed in meat products cooked at high temperatures. Many researchers reported that the natural additives such as rosemary, thyme, green tea, artichoke, grape seed, olive, clove reduce quality losses and improve microbiological quality. In this study, the studies investigating the effects of using plant-derived antioxidant and antimicrobial additives on the chemical, microbiological, sensory properties of the meatball and the effects of the formation of Heterocyclic amine (HCA) are presented.
\end{abstract}

Keywords: Antimicrobial, Antioxidant, Plant additive, HCA, Meatball

\section{Giriş}

Et ve et ürünlerinin yüksek miktarda proteini, demir, çinko, fosfor, magnezyum, selenyum gibi mineral maddelerini ve ayrıca B1, B6 ve B12 vitaminlerini, $\omega-3$ ve $\omega-6$ yağ asitlerini yeterli miktarda içermesi nedeniyle dengeli ve yeterli beslenme için ideal bir gıda maddesi olduğu bilinmektedir (Öztan 1993; Arihara 2006). Et ve et ürünleri bazı durumlarda ve uygun olmayan miktarlarda alındığında insan sağlığı açısından olumsuz etki gösterebilmektedir (Jimenez-Colmenero ve ark. 2001). Bu olumsuz etki etin içeriğinde bulunan yağ, doymuş yağ asidi ve kolesterol gibi bileşenlerin 
kardiyovasküler hastalıklar, bazı kanser türleri, obezite ve benzeri hastalıklarla ilişkilendirilmesinden kaynaklanmaktadır (Fernandez-Gines ve ark. 2005). Uluslararası Kanser Araştırmaları Birliği’nin (IARC) 2015 yılında yayınladığı raporda, kırmızı ve işlenmiş etlerin kanser riskini önemli düzeyde arttırdığı, kanser türleri arasında özellikle kalın bağırsak kanseri riskini arttırdığ 1 belirtilmiştir (IARC 2015).

Zengin besin içeriği et ve et ürünlerinin oksidatif ve mikrobiyal bozulmaya karşı duyarlı olmasına sebep olmaktadır (Contini ve ark. 2014; Shah ve ark. 2014). Et ve et ürünlerinde gerçekleşen lipid oksidasyonu, metal iyonları, oksijen ve sıcaklık faktörlerinden oldukça etkilenmekte ve ürünün duyusal olarak kabul edilebilirliğinde, renk, aroma ve lezzetinde istenmeyen değişikliklere yol açmaktadır. Oksidasyon reaksiyonlarının olumsuz etkilerini en aza indirgemek amacıyla antioksidanların kullanılması önemli bir çözüm yoludur (Descalzo ve ark. 2005; Guyon ve ark. 2016). Günümüzde tüketicilerin sağlıklı besinlere yönelmeleri ile birlikte sentetik antioksidanlar yerine yapısında polifenoller, flavonoidler ve organik asitler bulunan doğal bitkisel antioksidanların kullanımına yönelik çalışmalar artmıştır (Garcia-Lomillo ve ark. 2017a; Longato ve ark. 2017).

Gıda ürünleri üretim, işleme, dağıtım ve hazırlama sırasında mikrobiyal bulaşmaya maruz kalabilmekte, farklı türde mikroorganizmaların faaliyeti sonucunda ise üründe mikrobiyolojik bozulmalar meydana gelebilmektedir (Cueva ve ark. 2011; Gaulin ve ark. 2013). Ürüne patojen mikroorganizmaların bulaşması durumunda ise önemli sağlık riskleri oluşabilmekte, patojen veya toksinini içeren gıdaların tüketilmesi sonucunda gıda kaynaklı hastalıklar meydana gelebilmektedir. Salmonella spp., Staphylococcus aureus, Listeria monocytogenes gibi birçok patojen bazı durumlarda ölümle bile sonuçlanabilen hastalıklara neden olmaktadır (Oussalah ve ark. 2007). Hastalıklara neden olan bu mikroorganizmaların inhibisyonu amacıyla biberiye ekstraktı, üzüm çekirdeği ekstraktı, yeşilçay ekstraktı, nar kabuğu ekstraktı gibi antimikrobiyal özellikteki bitkisel kaynaklardan yararlanılabilmektedir (Georgantelis ve ark. 2007; Turgut ve ark. 2016; Dareddi ve ark. 2017). Bu bitkisel kaynaklar fenoller, fenolik asitler, kinonlar, saponinler, flavonoidler, tanenler, kumarinler, terpenoidler, alkaloidler ve hidroksil grupları gibi çoğunlukla mikroorganizmaların hücre membran yapısını bozan ve hücresel bileşenlerin hücre dışına çıkmasına neden olarak hücrenin ölümüne sebebiyet veren antimikrobiyal özellikteki bileşenleri içermektedirler (Lai ve Roy 2004; Ciocan ve Bara 2007; Daglia 2012).

Et ve et ürünlerinin yapısında oksidatif ve mikrobiyal değişimlerin yanı sıra pişme sırasında da bazı değişimler meydana gelmektedir. Özellikle et ve et ürünlerinin yüksek sıcaklıkta pişirilmesi sonucunda karsinojenik etkileri bulunan Heterosiklik aminler (HCA) oluşabilmektedir (Knize ve ark. 1997). HCA'ların diğer mutajenlerle karşılaştırılmaları sonucunda aflatoksin B1'den 100 kat, benzo [a] pirenden 2000 kat daha mutajenik oldukları bildirilmiştir (Öz ve Kaya 2011). HCA'ların oluşumu ve miktarları et türü, pH değeri, su aktivitesi, ortamda bulunan karbonhidratlar, serbest aminoasitler ve kreatin, pişirme süresi, pişirme sıcaklığı, pişirme ekipmanları ve yöntemleri gibi birçok faktöre bağlıdır (Knize ve ark. 1999; Öz ve Kaya 2011). Bugüne kadar 25'ten fazla farklı mutajenik HCA tanımlanmıştır (Öz ve Kızıl 2013). Üründe oluşan HCA miktarı doğal antioksidanların eklenmesiyle azaltılabilmektedir (Ahn ve Grün 2005; Gibis ve Weiss 2010; Quelhas ve ark. 2010; Öz ve Kaya 2011).

Son yıllarda et ve et ürünlerinin sağlıklı hale getirilmesi için farklı stratejiler geliştirilmekte ve uygulanan yöntemlerle et ürünleri modifiye edilerek besleyici özellikleri iyileştirilmektedir (Fernandez-Ginez ve ark. 2005). İşlenmiş et ürünlerinde kanserojen bileşiklerin oluşumu, ürünün formülasyonuna eklenen antioksidan, antimikrobiyal ve diğer katkılar ile engellenebilmekte ve böylelikle hem ürün kalitesi hem de sağlığını olumlu yönde etkileyen özellikler arttırılabilmektedir. Tüketicilerin et ürünlerine olumsuz yaklaşımlarını azaltmak için ürünlere doğal bitkisel katkıların eklenmesi etkin bir strateji olabilmektedir (Jimenez-Colmenero ve ark. 2001; Vitaglione ve Fogliano 2004; Hygreeva ve ark. 2014).

\section{Köfte Üretiminde Kullanılan Bitkisel Katkıların Üründe Oksidasyon Gelişimi ve Duyusal Özellikler Üzerine Etkileri}

Et ürünlerinde kimyasal bozulmaların başında gelen oksidatif bozulma; üründe renk değişikliğine, kötü lezzet oluşumuna, toksik bileşiklerin oluşumuna, raf ömrünün kısalmasına, besin maddesi ve damlama kayıplarına neden olmaktadır (Palmieri ve Sblendorio 2007; Contini ve ark. 2014; Shah ve ark. 2014). Et ve et ürünlerinde lipid oksidasyonu; başlama, yayılma ve serbest radikallerin oluştuğu sonlanma aşamalarını içeren üç adımlı bir zincir reaksiyonudur. Lipid oksidasyonu sonucunda oluşan bileşikler protein ve folik asit gibi gıda bileşenleriyle reaksiyona girmektedir. Bu bileşiklerin enzimleri inhibe ettiği, kandaki kolesterol ve peroksit seviyelerini arttırmasıyla kardiyovasküler hastalıklara neden olduğu bilinmektedir. Ayrıca oksidasyon ürünlerinin kanserojen etkileri olduğu rapor edilmiştir (Ames 1983; Frankel 1991). Lipid oksidasyonunu engellemek amacıyla kullanılan antioksidanlar, başlatıcı radikalleri süpürerek, zincir reaksiyonunu ve peroksitleri parçalayarak, lokalize oksijen konsantrasyonunu azaltarak ve metal iyonları gibi katalizörleri bağlayarak zincir reaksiyonlarını önlemektedirler (Dorman ve ark. 2003; Shah ve ark. 2014). Et ve et ürünlerinde butillendirilmiş hidroksianisol (BHA), bütillendirilmiş hidroksitoluen (BHT), tersiyer bütil hidrokinon (TBHQ) ve propil 
gallat (PG) gibi sentetik antioksidanlar yaygın olarak kullanılmaktadır (Jayathilakan ve ark. 2007; Karre ve ark. 2013). Bununla birlikte sentetik antioksidanların potansiyel toksikolojik etkileri nedeniyle doğal antioksidanlara olan talep gittikçe artmakta (Naveena ve ark. 2008), buna bağlı olarak son yıllarda et ürünleri formülasyonlarında bitkisel kaynaklı antioksidanların kullanımına dair bilimsel çalışmalar da artış göstermektedir.

Çeşitli bitkiler, baharatlar ve meyveler yüksek fenolik madde içerikleri nedeniyle sentetik antioksidanlara alternatif oluşturmaktadırlar (Nunez ark. 2008; Jiang ark. 2013). Yapılan bir çalışmada, sığır etinden üretilen köfte örneklerinde zerdeçal tozunun doğal antioksidan olarak kullanılabileceği, duyusal özellikler bakımından $\% 0.3$ oranında zerdeçal tozu ilavesinin kabul edilebilir olduğu ve bu uygulama ile ürünün besin kalitesinin de arttırılabileceği saptanmıştır (Milon ve ark. 2016). Erik püresinin az yağlı köfte üretiminde farklı miktarlarda kullanımının donmuş depolama süresince lipid oksidasyonunu yavaşlattığı belirlenmiştir (Yıldız-Turp ve Serdaroğlu 2010). Benzer bir çalışmada polifenol içeriği yüksek olan beyaz üzüm ekstraktının modifiye atmosferde paketlenmiş dana köftelerinde kullanımı ile 9 günlük depolama süresince lipid ve protein oksidasyonunun yavaşladığı saptanmış ve bu doğal katkının gelecek vadeden doğal bir antioksidan olduğu sonucuna varılmıştır (Jongberg ve ark. 2011). Doğal katkıların köfte örneklerinde kullanıldığı bazı çalışmalarda ürün duyusal özelliklerinin olumsuz etkilenebildiği gözlemlenmektedir. Yapılan bir çalışmada kuzu etinden üretilen köfte örneklerine demlenmiş şerbetçiotu ve şerbetçiotu tozunun eklenmesi ile üründe lipid ve protein oksidasyonunun azaldığı, şerbetçi otu tozunun demlenmiş şerbetçi otuna göre daha yüksek antioksidan aktivite gösterdiği belirlenmiştir. Bununla birlikte şerbetçi otu tozunun köfte örneklerinin duyusal kabul edilebilirlik puanlarında azalmaya neden olduğu belirtilmiş̧ir (Villalobos-Delgado ve ark. 2015). Yağı azaltılmış domuz köftesine \%5 oranında eklenen Laminaria japonica tozu (Choi ve ark. 2012), dana köftesine \%15 oranında eklenen keten tohumu unu (Bilek ve Turhan 2009) ve dana köftesine farklı oranlarda eklenen (\%2, \%4, \%6) zeytin küspesi (Hawashin ve ark. 2016) kullanımının da örneklerin genel kabul puanları üzerinde olumsuz etki oluşturduğu belirlenmiştir. Köfte üretiminde bitkisel katkıların kullanımının üründe oksidasyon gelişimi ve duyusal özellikler üzerine etkilerini inceleyen çalışmalar ve elde edilen sonuçlar Çizelge 1’de görülmektedir.

Çizelge 1. Köftede kullanılan bitkisel katkıların oksidasyon ve duyusal özellikler üzerine etkileri

\begin{tabular}{|c|c|c|c|}
\hline Örnek & $\begin{array}{l}\text { Etkisi İncelenen } \\
\text { Katkılar/Depolama } \\
\text { Parametreleri }\end{array}$ & Elde Edilen Bulgular & Kaynak \\
\hline $\begin{array}{l}\text { İsveç } \\
\text { Usulü } \\
\text { Dana } \\
\text { Köftesi }\end{array}$ & $\begin{array}{l}\text { Biberiye, } \\
\text { limon ve portakal } \\
\text { ekstraktları/ } \\
8^{\circ} \mathrm{C} \text { 'de } 12 \text { gün }\end{array}$ & $\begin{array}{l}\text { Biberiye ekstraktı içeren köfte örneklerinin diğer örnek } \\
\text { gruplarına göre daha düşük TBARS değerlerine sahip oldukları } \\
\text { belirlenmiştir. }\end{array}$ & $\begin{array}{l}\text { Fernandez- } \\
\text { Lopez ve } \\
\text { ark. } 2005\end{array}$ \\
\hline $\begin{array}{l}\text { Dana } \\
\text { Köftesi }\end{array}$ & $\begin{array}{l}\text { Mersin, biberiye, } \\
\text { 1sirgan ve limon otu } \\
\text { ekstraktları }(\% 10) / \\
-20 \pm 2^{\circ} C^{\prime} \text { de } 120 \text { gün }\end{array}$ & $\begin{array}{l}\text { Mersin ekstraktının TBARS değeri üzerine en etkili katkı olduğu, } \\
\text { bunu sırasıyla biberiye, limon otu ve ısırgan ekstraktlarının } \\
\text { izlediği saptanmıştır. Eklenen katkıların genel kabul edilebilirlik } \\
\text { puanlarını arttırdığı gözlenmiştir. En yüksek tad, renk ve koku } \\
\text { puanları mersin ve biberiye ekstraktları eklenen örneklerde } \\
\text { belirlenmiştir. }\end{array}$ & $\begin{array}{l}\text { Akarpat ve } \\
\text { ark. } 2008\end{array}$ \\
\hline $\begin{array}{l}\text { Tavuk } \\
\text { Köftesi }\end{array}$ & $\begin{array}{l}\text { Nar suyu, } \\
\text { nar kabuğu tozu } \\
\text { ekstraktı ve } \mathrm{BHT} / \\
4^{\circ} \mathrm{C} \text { 'de } 15 \text { gün }\end{array}$ & $\begin{array}{l}\text { Nar kabuğu tozu ekstraktının depolama süresince lipid } \\
\text { oksidasyonu üzerine en etkili katkı olduğu saptanmıştır. Katkı } \\
\text { kullanılan örnekler ve kontrol örneği arasında değerlendirilen } \\
\text { duyusal özellikler bakımından önemli bir farklılık } \\
\text { gözlenmemiştir. }\end{array}$ & $\begin{array}{l}\text { Naveena } \\
\text { ve ark. } \\
2008\end{array}$ \\
\hline $\begin{array}{l}\text { Domuz } \\
\text { Köftesi }\end{array}$ & $\begin{array}{l}\text { İki avokado çeşidinin } \\
\text { (Hass ve Fuerte) kabuk, } \\
\text { posa ve çekirdek } \\
\text { ekstraktları/ } \\
4^{\circ} \mathrm{C}^{\prime} \text { de } 15 \text { gün }\end{array}$ & $\begin{array}{l}\text { Avokado ekstraktları eklenen köfte örneklerinin, kontrol } \\
\text { örneğine kıyasla daha düşük TBARS değerlerine sahip olduğu } \\
\text { ve 'Hass' avokado çeşidinin protein karbonilleri oluşumunu } \\
\text { önemli ölçüde engellediği belirlenmiştir. }\end{array}$ & $\begin{array}{l}\text { Rodríguez- } \\
\text { Carpena } \\
\text { ve ark. } \\
2011\end{array}$ \\
\hline $\begin{array}{l}\text { Dana } \\
\text { Köftesi }\end{array}$ & $\begin{array}{l}\text { Zeytin yaprağ1, yaban } \\
\text { mersini ve hünnap } \\
\text { ekstraktları (500 ve } \\
\text { 1000ppm) / } \\
4^{\circ} \mathrm{C} \text { 'de } 10 \text { gün }\end{array}$ & $\begin{array}{l}\text { Zeytin yaprağı ekstraktının } 1000 \text { ppm oranında kullanımı lipid } \\
\text { oksidasyonu üzerine en etkili katkı ve oranı olarak belirlenmiştir. } \\
\text { Duyusal olarak en yüksek düzeyde puan alan ve rengin en iyi } \\
\text { korunduğu örneklerin, } 1000 \text { ppm oranında yaban mersini içeren } \\
\text { köfte örnekleri olduğu saptanmıştır. }\end{array}$ & $\begin{array}{l}\text { Gök ve } \\
\text { Bor, } 2012\end{array}$ \\
\hline
\end{tabular}


Çizelge 1. Köftede kullanılan bitkisel katkıların oksidasyon ve duyusal özellikler üzerine etkileri (devamı)

\begin{tabular}{|c|c|c|c|}
\hline $\begin{array}{l}\text { Dana } \\
\text { Köftesi }\end{array}$ & $\begin{array}{l}\text { Isırgan otu ekstraktı ve } \\
\text { E vitamini ( } 250 \mathrm{ppm} \text { ve } \\
500 \mathrm{ppm}) / 4^{\circ} \mathrm{C} \text { 'de } 9 \text { gün }\end{array}$ & $\begin{array}{l}250 \text { ppm 1sırgan otu ekstraktı eklenen örnek grubunda lipid } \\
\text { oksidasyonu diğer örnek gruplarından daha düşük düzeyde } \\
\text { saptanmıştır. }\end{array}$ & Oz 2014 \\
\hline $\begin{array}{l}\text { Balık } \\
\text { Köftesi }\end{array}$ & $\begin{array}{l}\text { Kekik }(880 \mu \mathrm{l} / \mathrm{kg}) \text {, } \\
\text { karanfil }(2.65 \mu \mathrm{l} / \mathrm{kg}) \text { ve } \\
\text { biberiye }(8.5 \mu \mathrm{l} / \mathrm{kg}) \\
\text { esansiyel } \\
\text { yağları } / 4^{\circ} \mathrm{C}^{\prime} \text { 'de } 14 \text { gün }\end{array}$ & $\begin{array}{l}\text { TBARS değeri üzerine en etkili katkının biberiye olduğu, } \\
\text { ardından karanfilin geldiği belirlenmiştir. Raf ömrünün kontrol } \\
\text { grubu için } 4 \text {, katkı ilave edilen gruplar için sırasıyla } 8,10 \text { ve } 14 \\
\text { güne kadar uzadığı sonucuna varılmıştır. Katkı eklenen } \\
\text { örneklerin duyusal değerlendirme puanlarının kontrol örneklerine } \\
\text { göre daha yüksek olduğu saptanmıştır. }\end{array}$ & $\begin{array}{l}\text { Guran ve } \\
\text { ark. } 2015\end{array}$ \\
\hline $\begin{array}{l}\text { Tavuk } \\
\text { Köftesi }\end{array}$ & $\begin{array}{l}\text { Yeşil lahana }(\% 15, \\
\% 25) / 4^{\circ} C^{\prime} \text { de } 9 \text { gün }\end{array}$ & $\begin{array}{l}\text { Depolamanın sonunda \% } \% 25 \text { yeşil lahana eklenen örnek grubunun } \\
\text { TBARS değerlerinin diğer örnek gruplarından daha düşük olduğu } \\
\text { saptanmıştır. } \\
\text { Lahana ilavesiyle görünüm, renk, koku, sululuk, tekstür, sertlik } \\
\text { ve genel kabul puanları artış göstermiş, lezzet puanları ise } \\
\text { düşmüştür. Depolama süresince tüm puanlarda düşme } \\
\text { gözlemlenmiştir. }\end{array}$ & $\begin{array}{l}\text { Verma ve } \\
\text { ark. } 2016\end{array}$ \\
\hline $\begin{array}{l}\text { Tavuk } \\
\text { Köftesi }\end{array}$ & $\begin{array}{l}\text { Erik posası ve erik } \\
\text { kabuğu } \\
\text { mikropartikülleri }(\% 2) / \\
4^{\circ}{ }^{\circ} \text { 'de } 10 \text { gün }\end{array}$ & $\begin{array}{l}\text { Erik posası ve erik posası mikropartikülleri eklenmiş köfte } \\
\text { örneklerinin TBARS değerlerinin kontrol örneklerinden daha } \\
\text { düşük olduğu saptanmıştır. }\end{array}$ & $\begin{array}{l}\text { Basanta ve } \\
\text { ark. } 2017\end{array}$ \\
\hline $\begin{array}{l}\text { Dana } \\
\text { Köftesi }\end{array}$ & $\begin{array}{l}\text { Liyofilize edilmiş nar } \\
\text { kabuğu nanopartikülleri } \\
\text { (LPP-NPs) (\%1, \%1.5) } \\
\text { ve } \quad \text { BHT } \\
(\% 0.01) / 4^{\circ} \mathrm{C}^{\prime} \text { de } 15 \text { gün }\end{array}$ & $\begin{array}{l}\text { Artan oranda nar kabuğu nanopartikülleri kullanımının TBARS } \\
\text { değerlerini düşürdüğ̈̈ belirlenmiştir. BHT ve LPP-NPs eklenmiş } \\
\text { örnekler arasında ilk } 9 \text { gün boyunca önemli bir farklılık } \\
\text { gözlenmemiştir. }\end{array}$ & $\begin{array}{l}\text { Morsy ve } \\
\text { ark. } 2018\end{array}$ \\
\hline
\end{tabular}

*. TBARS: Tiyobarbiturik asit reaktif maddesi

\section{Köfte Üretiminde Kullanılan Bitkisel Katklların Ürünün Mikrobiyolojik Özellikleri Üzerine Etkileri}

Sağlıklı hayvanların etleri steril kabul edilmesine karşın, etlere uygulanan kesme, yüzme, parçalama, depolama gibi işlemler ile etin ürüne işlenmesi aşamasında kullanılan hammadde (et, yağ ve baharatlar), ekipman ve üretimi yapan personele bağlı mikrobiyal bulaşmalar olmaktadır (Öztürk ve ark. 2010). Et ve et ürünlerinde meydana gelen mikrobiyal gelişme, ürün kalite kaybına neden olan ve raf ömrünü etkileyen en önemli faktörlerdendir. Bununla birlikte gıda kaynaklı hastalıklar arasında et ve et ürünleri tüketimi sonucunda oluşan hastalıklar önemli bir paya sahiptir. Son yıllarda bütün Dünya' da artış gösteren gıda kaynaklı hastalık vakalarında hayvansal kaynaklı ürünlerin önemli bir yer tuttuğu ve bu ürün grubunda Salmonella türlerinin, Escherichia coli O157:H7 ve Listeria monocytogenes gibi patojenlerin hastalıklardan sorumlu mikroorganizmalar olarak ön plana çıktığı bildirilmektedir (CDC 2015). Et ve ürünlerinin mikrobiyolojik açıdan kaliteli ve güvenilir olması adına gıda endüstrisinde ısıl işlem, soğukta veya dondurarak depolama, modifiye atmosferde veya vakum paketleme, fermentasyon, marinasyon, tütsüleme, kürleme, antimikrobiyal etki gösteren katkıların formülasyonda kullanımı gibi uygulamalardan yararlanılmaktadır (Lawrie ve Ledward 2006; Zhou ve ark. 2010). Son yıllarda en yaygın kullanım alanı bulan uygulamalardan biri de, farklı bitkisel kaynaklar ve bu kaynaklardan elde edilen yan ürünlerin antimikrobiyal ajanlar olarak et ürünlerinde kullanımıdır. Bu ürün grubunda antimikrobiyal etkisi incelenmiş olan bitkisel katkılar arasında kekik, limon, sarımsak, biberiye, maydanoz, tarçın, karanfil, kişniş, kimyon, kuşburnu, mercanköşk, limon, adaçayı, yeşilçay, vanilin, gargat ağacı meyvesi, çördük, enginar, nar ve domates, zeytin, kırmızı üzüm ve yan ürünleri yer almaktadır.

Hawashin ve ark. (2016) tarafından yapılan bir çalışmada köfte üretiminde kullanılan zeytin küspesi oranının arttırılması $(\% 2,46)$ ile köftenin kalite özelliklerinin iyileştiği ve toplam aerobik mezofilik bakteri sayısında yaklaşık 4 logaritmik birim azalma sağlandığı belirlenmiştir. Bu çalışmada, zeytin küspesinin köftelerin raf ömrünü uzatmak amacıyla kullanılabilecek bir alternatif olduğu sonucuna varılmıştır.

Garcia-Lomillo ve ark. (2017b) tarafından yapılan bir çalışmada, farklı tuz oranları (\%1, 1.5, 2) kullanılarak üretilen sı̆̆ır eti köftelerine kırmızı şarap posasından elde edilen baharat eklenmiş (\%2 oranında) ve baharat ilave edilen ve özellikle düşük tuz oranlarına sahip örneklerde, toplam mezofilik aerobik bakteri ve laktik asit bakterisi gelişiminin geciktiği tespit edilmiştir. 
Yapılan başka bir çalışmada, liyofilize edilmiş nar kabuğu nanopartikülleri sığır köftelerine eklenmiş ve kullanılan katkının antimikrobiyal ve antioksidan etkileri depolama süresince $\left(4^{\circ} \mathrm{C}\right.$ 'de 15 gün) incelenmiștir (Morsy ve ark. 2018). Çalışmada, \%1 ve \%1.5 oranında liyofilize edilmiş nar kabuğu nanopartikülleri içeren örneklerin toplam mikrobiyal yükünün, depolama süresince kontrol grubuna oranla daha düşük olduğu belirlenmiştir. Bununla birlikte kullanılan katkının köftelerin renginde olumsuz bir değişime neden olmadığı, ancak depolamanın son günlerinde renk ve koku skorlarında anlamlı derecede azalma olduğu belirtilmiştir.

Koyun köftesine yer fistığı kabuğu ekstraktı (1000 ppm) eklenerek yapılan bir çalışmada, yer fistığı kabuğu ekstraktının, depolama sonunda kontrol grubuna kıyasla ürünün doğal florasında bulunan laktik asit bakterisi ve Pseudomonas spp. sayılarında azalma sağladığ 1 tespit edilmiştir. Bununla birlikte, kullanılan katkının depolama boyunca lipid ve protein oksidasyonunu engelleyici etki gösterdiği ve ürünün duyusal özelliklerini iyileştirdiği belirlenmiştir (Munekata ve ark. 2016).

Ibrahim ve ark. (2011) tarafından yapılan başka bir çalışmada, jojoba, jatropha, ginseng ve zancefil ekstraktları kuzu köftesine ayrı ayrı ilave edilmiş ve elde edilen ürünün kalite özellikleri incelenmiştir. $4^{\circ} \mathrm{C}$ 'de 9 gün depolama sonunda örneklerin kontrol grubuna kıyasla toplam mezofilik aerobik bakteri sayısında sırasıyla 2.63, 2.61, 2.75 ve 2.73 log CFU/g; küf ve maya sayısında ise $1.07,1.07,1.15$ ve $0.87 \log \mathrm{CFU} / \mathrm{g}$ azalma sağladığ gözlemlenmiştir. Köfte üretiminde kullanılan bitkisel katkıların ürünün mikrobiyolojik kalitesi üzerine etkilerinin incelendiği çalışmalar Çizelge 2'de özetlenmiştir.

Çizelge 2. Köftede kullanılan bitkisel katkıların mikrobiyolojik özellikler üzerine etkisi

\begin{tabular}{|c|c|}
\hline Ürün & Etkisi İncelenen Katkı \\
\hline $\begin{array}{l}\text { Sığır } \\
\text { Köftesi }\end{array}$ & $\begin{array}{l}\text { Yeşil yapraklı sebze ekstraktları (Fuki, } \\
\text { Pimpinella brachycarpa, Çin lahanası, Çin } \\
\text { frenk soğanı, taç papatya, Japon çıarı, } \\
\text { balkabağı, susam, damkoruğu, brokoli) (\% } \\
0.1 \text {, 0.5) kullanımının } 4^{\circ} \mathrm{C} \text { 'de } 12 \text { gün } \\
\text { depolanan sığı köftelerinde mikrobiyal } \\
\text { yük üzerine etkisi }\end{array}$ \\
\hline $\begin{array}{l}\text { Domuz } \\
\text { Köftesi }\end{array}$ & $\begin{array}{l}\text { Kahverengi deniz yosunu } \text { (Laminaria } \\
\text { digitata) ekstraktı (\%0.01, } 0.1, \quad 0.5) \\
\text { kullanımının } 4^{\circ} \mathrm{C} \text { 'de } 14 \text { gün depolanan } \\
\text { domuz köftelerinin mikrobiyolojik kalitesi } \\
\text { üzerine etkisi }\end{array}$ \\
\hline $\begin{array}{l}\text { Sığır } \\
\text { Köftesi }\end{array}$ & $\begin{array}{l}\text { Gargat ağac meyve (Nitraria retusa) } \\
\text { ekstraktının }(\% 0.5,0.75,1) \text { kullanımının } \\
4^{\circ} \mathrm{C} \text { 'de } 9 \text { gün depolanan örneklerde } \\
\text { mikrobiyolojik kalite üzerine etkisi }\end{array}$ \\
\hline
\end{tabular}

Bizon Karanfil esansiyel yağı $(\% 0.1)$ ve üzüm Köftesi çekirdeği ekstraktı $(\% 0.1$ ve $\% 0.2)$ kullanımının $8^{\circ} \mathrm{C}^{\prime}$ de 9 gün depolanan örneklerde mikrobiyolojik kalite üzerine etkisi

Dana Nar kabuğu ekstraktı $\quad(\% 0.1,0.2,0.3)$

Köfte kullanımının $4^{\circ} \mathrm{C}^{\prime}$ de 6 gün depolanan köftelerin mikrobiyolojik kalitesi ve güvenliği üzerine etkisi

Tekirdağ Biberiye, limon, kekik, sarımsak Köftesi ekstraktları (\%0.1) kullanımının $4^{\circ} \mathrm{C}$ 'de 7 gün depolanan Tekirdağ köftelerinin mikrobiyolojik kalite ve güvenliği üzerine etkisi

\begin{tabular}{ll}
\multicolumn{1}{c}{ Elde Edilen Bulgular } & \multicolumn{1}{c}{ Kaynak } \\
\hline En yüksek antimikrobiyal etkiyi $P$. brachycarpa ve Japon çınarı göstermiştir. & Kim ve \\
Koliform bakteriler üzerinde \%0.1 ve \%0.5 oranları için sırasıyla 0.94 ve & ark. 2013 \\
1.03 log azalma sağlamıştır. & \\
\%0.1 katkılı örneklerin mikrobiyal yükü \%0.5 katkılı örneklere kıyasla daha & \\
yüksek bulunmuştur. &
\end{tabular}

Deniz yosunu ekstraktı, $4^{\circ} \mathrm{C}$ 'de 14 gün depolama süresince köftelerin toplam mezofilik ve psikrofilik bakteri sayısı üzerinde önemli bir etki göstermemiştir.

Moroney ve ark. 2013

$N$. retusa meyve özütü ilavesi mikrobiyal gelişimi önemli ölçüde azaltmıştır. Psikrofilik bakterileri sayılarında artan ekstrakt oranlarında sırasıyla $1.71 \mathrm{log}$ $\mathrm{CFU} / \mathrm{g}, 2.19 \log \mathrm{CFU} / \mathrm{g}, 2.58 \log \mathrm{CFU} / \mathrm{g}$ azalma sağlanmıştır. Ekstraktlar en çok koliform bakteriler üzerine etkili bulunmuştur. Artan ekstrakt oranlarında sirasıyla $1.99 \log \mathrm{CFU} / \mathrm{g}, 2.34 \log \mathrm{CFU} / \mathrm{g}, 2.66 \log \mathrm{CFU} / \mathrm{g}$ azalma sağlanmıştır.

Karanfil yağı kullanımı Pseudomonas spp., psikrofilik bakteri ve laktik asit bakterilerinin gelişimini engellerken mezofilik bakterilerin gelişimini etkilememiştir. Kontrol örneklerinde L. monocytogenes sayısında meydana gelen artışın, üzüm çekirdeği ekstraktı içeren örneklere kıyasla daha fazla olduğu saptanmıştır.

$\% 0.2$ ve $\% 0.3$ oranlarında nar kabuğu ekstraktı kullanımı, köfte örneklerine inoküle edilen S. aureus üzerinde antimikrobiyal etki göstermiştir. Ayrıca Enterobacteriaceae sayıları için sırasıyla 1.11 ve 1.25 log azalma sağladığ belirlenmiştir. Kontrol ile karşılaş̧ırıldığında toplam mezofilik bakteri sayısı nar kabuğu ekstraktı ilavesi ile yaklaşık $1 \log$ azalmıştır.

Depolamanın sonunda kontrol grubuna kıyasla; Toplam mezofilik aerobik bakterilere karş1, biberiye ( $0.37 \log$ azalma) ve sarımsak ( $0.23 \log$ azalma); koliform grubuna karş1 limon (0.22 log azalma) ve biberiye (0.19 log azalma); E. coli'ye karşı limon (3.52 log azalma); S. aureus'a karşı biberiye (0.29 log azalma) ve kekik (0.25 log azalma); maya ve küfe karşı kekik (0.38 log azalma) ve sarımsak (0.03 log azalma) en etkili ekstraktlar olarak belirlenmiştir.
Mariem ve ark. 2014

Tajik ve ark. 2014

Özdemir ve ark. 2014

Özen ve Çoşkun 2014 
Çizelge 2. Köftede kullanılan bitkisel katkıların mikrobiyolojik özellikler üzerine etkisi (devamı)

\begin{tabular}{|c|c|c|c|}
\hline Ürün & Etkisi İncelenen Katkı & Elde Edilen Bulgular & Kaynak \\
\hline $\begin{array}{l}\text { Kuzu } \\
\text { Köftesi }\end{array}$ & $\begin{array}{l}\text { Domates, kırmızı üzüm, } \\
\text { zeytin, nar yan ürünlerinin (1000 ppm) } \\
2 \pm 1^{\circ} \mathrm{C} \text { 'de modifiye atmosferde } 7 \text { gün } \\
\text { depolanan kuzu köftelerinin } \\
\text { mikrobiyolojik kalitesi üzerine etkisi }\end{array}$ & $\begin{array}{l}\text { Depolama sonunda kontrol ile kıyaslandığında domates ve nar yan } \\
\text { ürünlerinin diğer katkılara oranla daha yüksek antimikrobiyal etki gösterdiği, } \\
\text { domates ve nar yan ürününün sırasıyla; toplam psikrofilik bakteri sayısında } \\
0.91 \text { ve } 1.01 \mathrm{log} \text {, toplam mezofilik bakteri sayısında } 1.26 \text { ve } 1.18 \text { log, } \\
\text { Enterobacteriaceae sayısında } 1.85 \text { ve } 1.32 \log \text {, laktik asit bakterisi sayısında } \\
1.29 \text { ve } 1.26 \text { log azalma sağladığı saptanmıștır. }\end{array}$ & $\begin{array}{l}\text { Andres } \\
\text { ve ark } \\
2017\end{array}$ \\
\hline $\begin{array}{l}\text { Sığır } \\
\text { köftesi }\end{array}$ & $\begin{array}{l}\text { Kitosan nanopartikülleri ile enkapsüle } \\
\text { edilmiş tarçın esansiyel yağları }(\% 0.05 \text {, } \\
0.1) \text { kullanımının } 4^{\circ} \mathrm{C}^{\prime} \text { de } 8 \text { gün depolanan } \\
\text { sığır köftelerinin mikrobiyolojik kalite ve } \\
\text { güvenliği üzerine etkisi }\end{array}$ & $\begin{array}{l}\text { Depolama süresince katk1 ilaveli örnekde (\%0.05 ve } 0.1) \text { kontrol grubuna } \\
\text { kiyasla sırasıyla; toplam mezofilik aerobik bakteri sayısında } 2.23 \text { ve } 2.86 \log \text {, } \\
\text { S. aureus sayısında } 2.86 \text { ve } 2.26 \text { log, Enterobacteriaceae sayısında } 3.23 \text { ve } \\
3.86 \log \text {, küf ve maya sayısında } 3.16 \text { ve } 1.92 \text { log azalma gözlemlenmiștir. }\end{array}$ & $\begin{array}{l}\text { Ghaderi- } \\
\text { Ghahfaro } \\
\text { khi ve } \\
\text { ark. } 2017\end{array}$ \\
\hline $\begin{array}{l}\text { Tavuk } \\
\text { köftesi }\end{array}$ & $\begin{array}{l}\text { Biberiye ve yeşil çay ekstraktı }(\% 2) \\
\text { kullanımının } 4^{\circ} \mathrm{C} \text {,de } 8 \text { gün depolanan } \\
\text { tavuk köftelerinin mikrobiyolojik kalitesi } \\
\text { üzerine etkisi }\end{array}$ & $\begin{array}{l}\text { Yeşil çay ekstraktı kullanımı depolama boyunca örneklerin toplam mezofilik } \\
\text { bakteri ve koliform sayılarında sırasıyla } 2.47 \text { ve } 5.15 \mathrm{log} \text {, biberiye ekstraktı } \\
\text { kullanımı ise } 2.18 \text { ve } 4.34 \text { log azalma sağlamıştır. }\end{array}$ & $\begin{array}{l}\text { Reddy ve } \\
\text { ark. } 2017\end{array}$ \\
\hline Dana köfte & $\begin{array}{l}\text { Çördük (Echinophora tenuifolia subsp. } \\
\text { sibthorpiana) }(\% 0.5,1,1.5) \text { kullanımının } \\
4^{\circ} \mathrm{C} \text { 'de } 7 \text { gün depolanan örneklerde } \\
\text { Salmonella Typhimurium üzerine etkisi }\end{array}$ & $\begin{array}{l}\text { Çördük kullanımı Salmonella Typhimurium sayısını, kullanılan orana bağlı } \\
\text { olarak 0.35-1.0 log aralığında değişen seviyelerde azaltmıştır. En yüksek etki } \\
\% 1.5 \text { çördük kullanımı ile sağlanmıştır. Depolama sonunda en yüksek oranda } \\
\text { çördük içeren örneklerde en düşük mezofilik aerobik bakteri sayısı tespit } \\
\text { edilmiştir. }\end{array}$ & $\begin{array}{l}\text { Sengun } \\
\text { ve ark. } \\
2017\end{array}$ \\
\hline $\begin{array}{l}\text { Sığır } \\
\text { röftesi }\end{array}$ & $\begin{array}{l}\text { Enginar ekstraktı }(500 \text { ve } 1000 \mathrm{ppm}) \\
\text { kullanımının } 4^{\circ} \mathrm{C}^{\prime} \text { de } 7 \text { gün depolanan sığır } \\
\text { köftelerinin mikrobiyolojik kalite ve } \\
\text { güvenliği üzerine etkisi }\end{array}$ & $\begin{array}{l}500 \text { ppm enginar ekstraktı kullanımı, köftelere inoküle edilen } E \text {. coli ve } L \text {. } \\
\text { monocytogenes sayısını sırasıyla } 3.04 \text { ve } 0.73 \text { log, } 1000 \text { ppm enginar } \\
\text { ekstraktı kullanımı ise } 3.5 \text { ve } 1.15 \log \text { düşürmüştür. } \\
\text { Kullanılan ekstrakt konsantrasyona bağlı olarak toplam psikrofilik bakteri } \\
\text { sayıs1 } 2.5 \text { log azalmıştır. Depolama sonunda koliform bakteri sayıs } 500 \text { ppm } \\
\text { ve } 1000 \text { pmm katkı içeren örneklerde sırasıyla } \% 6 \text { ve } \% 20 \text { oranlarında } \\
\text { azalmıștır. }\end{array}$ & $\begin{array}{l}\text { Ergezer } \\
\text { ve ark. } \\
2018\end{array}$ \\
\hline
\end{tabular}

Köfte Üretiminde Kullanılan Bitkisel Katkıların Heterosiklik Amin (HCA) Oluşumu Üzerine Etkileri

Et ve et ürünlerinin $150^{\circ} \mathrm{C}$ ve daha yüksek sıcaklıklarda pişirilmesiyle kreatin, şekerler ve aminoasitlerin Maillard reaksiyonu sonucunda heterosiklik aromatik aminler oluşmaktadır. HCA'lar pişmiş gıdalarda ng/g düzeylerinde bulunmaktadır (Keşkekoğlu ve Üren 2014). Bu bileşiklerin oluşumu pişirme metodu, pişirme süresi, pişirme sicaklığı ve et çeşidi gibi faktörlere bağlı olarak gerçekleşmektedir. Heterosiklik aminlerin yapılarında heterosiklik halkalar ve azot içeren gruplar bulunmaktadır. Pişmiş et ürünlerinde en çok belirlenen HCA'lar 2-amino-3,8-dimetilimidazo [4,5-f] kinokzalin (MeIQx), 2-amino-3,4,8-trimetilimidazo[4,5f]kinokzalin (4,8-DiMeIQx) ve 2-amino-1-metil-6fenilimidazo[4,5-b] piridin (PhIP)'dir (Persson ve ark. 2003; Janoszka ve ark. 2009; Puangsombat ve ark. 2011; Çiçek ve Bulgan 2013). Kolon, pankreas, gastrointestinal sistem, akciğer, karaciğer, prostat, cilt ve meme kanseri riskleri HCA tüketimi ile ilişkilendirilmektedir. Uluslararası Kanser Araştırma Ajansı (IARC) kırmızı eti muhtemel kanserojen, işlenmiş et ürünlerini ise kanserojen olarak tanımlamış ve et tüketimi ile kanser arasında ilişki olduğunu bildirmiştir. Ayrıca kırmızı et ve işlenmiş et ürünlerinde pişirme işlemi sonrası oluşan HCA bileşiklerinden bazılarını (MeIQ, MeIQx ve PhIP) mümkün insan kanserojeni (sınıf 2B) olarak, IQ bileşiğini ise muhtemel insan kanserojeni (sınıf 2A) olarak kabul etmiştir (IARC 1993; IARC 2017). Yapılan çalışmalarda HCA konsantrasyonlarının, ürüne E vitamini veya antioksidan içeren baharatlar, biberiye, sarımsak, adaçayı, kekik, yeşil çay, meyve veya üzüm çekirdeği gibi katkılar eklenmesiyle azaltılabileceği ortaya konulmuştur (Ahn ve Grün 2005).

Keşkekoğlu ve Üren (2014) yaptıkları bir çalışmada, nar çekirdeği ekstraktı eklenen dana ve tavuk köftelerinde farklı pişirme yöntemlerinin HCA oluşumu üzerine etkilerini araştırmışlardır. Nar çekirdeğinin dana köftelerinde toplam HCA oluşumunu, barbekü ve yağda kızartma ile pişirme yöntemleri sonucunda sırasıyla \%39 ve \%46 oranlarında azalttığı gözlemlenmiştir. Başka bir çalışmada, hibisküs ekstraktının; dana köftelerinde duyusal olarak herhangi bir olumsuzluğa neden olmadan HCA oluşumunu engelleyebileceği belirlenmiştir (Gibis ve Weiss 2010).

Öz ve Kaya (2011) yaptıkları bir çalışmada \%30 yağlı dana köftelerinde kullanılan karabiberin HCA üzerine etkisini araştırmışlardır. Karabiber içermeyen kontrol grubu örneklerinde toplam HCA miktarının kızartma sıcaklığının artmasına bağlı olarak arttığı saptanmıştır. Karabiber kullanımının toplam HCA oluşumu üzerinde yaklaşık \%12 ile \%100 arasında değişen azaltıcı bir etkiye sahip olduğu sonucuna varılmıştır. Benzer şekilde yapılan bir çalışmada sığır köftesine zeytin ekstraktı, elma ekstraktı, soğan tozu, karanfil tomurcuğu yağı ayrı ayrı eklenerek 1zgarada pişirme işlemi uygulanmış, zeytin ekstraktı ve soğan tozu kullanımının örneklerde MeIQx ve PhIP oluşumunu azalttığı belirlenmiştir. Bunun yanında \%1 oranında elma ekstraktı kullanımının MeIQx üzerinde herhangi bir etkisi bulunmadı̆̆ı ve PhIP 
miktarında $\% 12.8$ oranında bir artışa neden olduğu tespit edilmiş, örneklere $\% 0.3$ ve $\% 0.5$ oranında karanfil yağ ilavesinin PHIP düzeyini sırasıyla \%21 oranında azalttığ ve \% 23.1 oranında arttırdığı saptanmıștır (Rounds ve ark. 2013). Yapılan başka bir çalışmada; biberiye, kekik, adaçayı, sarımsak gibi çeşitli bitkisel katkıların sığır etinden üretilen köftelerin yüzeyine eklenip kızartılması ile HCA oluşumu arasındaki ilişki incelenmiş ve IQ, MeIQ, 4,8-DiMeIQx, MeIQx ve PhIP düzeylerinde kekiğin \%61-100, sarımsağın \%32-78, biberiyenin \%38-75 ve adaçayının ise \%40-100 azalma sağladığı bildirilmiştir (Murkovic ve ark. 1998).

\section{Sonuç}

İnsan sağlığı açısından önemli bir yere sahip olan et ve et ürünleri, yüksek besleyici içeriğinden dolayı yetersiz beslenmeye çözüm olabilecek temel bir gıda maddesi olarak görülmektedir. Ancak et ve et ürünleri kolayca okside olabilmekte ve mikrobiyolojik bozulmaya uğrayabilmektedir. Bu bozulmalar üründe kalite kayıplarına neden olmakla kalmayıp, bu ürünlerin tüketilmesi durumunda tüketicilerde gıda kaynaklı sağlık problemlerine de neden olabilmektedir. Yapılan çalışmalarda köfte üretiminde sentetik katkılara alternatif olarak çeşitli bitkisel katkıların kullanımının denendiği ve bu katkıların üründe oksidasyon gelişimi ve mikrobiyal bozulma üzerinde önemli düzeyde etki sağlayarak ürünün raf ömrünü uzattığı, ayrıca etin yüksek sıcaklıklarda pişirilmesi sonucu oluşan ve mutajen-kanserojen olarak kabul edilen HCA üzerinde de azaltıcı etki gösterdiği belirlenmiştir. Bitkisel katkıların köftede HCA oluşumu üzerine etkilerinin incelendiği sınırlı sayıdaki çalışma sonuçlarının umut verici olması, bu konuda daha fazla çalışmanın yapılması gerekliliğini ortaya koymuştur. Yapılan çalışma sonuçları incelendiğinde, Ülkemizde ve tüm Dünya'da sevilerek tüketilen köftede sentetik katkılar yerine bitkisel katkıların kullanımı ile yeniden formüle edilmiş, raf ömrü uzun, pişirme işlemi sırasında HCA oluşumu azaltılabilmiş daha sağlıklı et ürünü eldesinin mümkün olabildiği görülmektedir. Bununla birlikte köfte üretiminde bitkisel katkıların ürün duyusal özelliklerini olumsuz yönde etkilemeden uygun oranlarda kullanımını belirlemek üzere daha fazla çalışma yapılmalı, bu çalışmalardan elde edilen sonuçların ticarileştirilmesi adına gerekli adımlar atılmalıdır.

\section{Kaynaklar}

Ahn J, Grün IU (2005). Heterocyclic amines: 2. Inhibitory effects of natural extracts on the formation of polar and nonpolar heterocyclic amines in cooked beef. Journal of Food Science. 70(4). DOI: 10.1111/j.1365-2621.2005.tb07171.x.

Akarpat A, Turhan, S, Ustun NS (2008). Effects of hot-water extracts from myrtle, rosemary, nettle and lemon balm leaves on lipid oxidation and color of beef patties during frozen storage. Journal of Food Processing and Preservation. 32(1), 117-132. DOI: 10.1111/j.1745-4549.2007.00169.x.

Andres AI, Petron, MJ, Adamez JD, López M, Timon ML (2017). Food by-products as potential antioxidant and antimicrobial additives in chill stored raw lamb patties. Meat Science.129, 62-70. DOI: 10.1016/j.meatsci.2017.02.013.

Arihara K. (2006). Strategies for designing novel functional meat products. Meat Science. 74(1), 219-229.

Ames BM (1983). Dietary carcinogens and anticarcinogens: oxygen radical and degenerative diseases. Meat Science. 221, 1256-1263, 1983. DOI:10.1016/j.meatsci.2006.04.028.

Frankel EN (1991). Recent advances in lipid oxidation. Journal of the Science of Food and Agriculture. 54(4), $495-511$. DOI: $10.1002 /$ jsfa.2740540402.

Basanta MF, Rizzo SA, Szerman N, Vaudagna SR, Descalzo AM, Gerschenson LN, Perez CD, Rojas, AM (2017). Plum (Prunus salicina) peel and pulp microparticles as natural antioxidant additives in breast chicken patties. Food Research International. DOI: 10.1016/j.foodres.2017.12.011.

Bilek AE, Turhan S. (2009). Enhancement of the nutritional status of beef patties by adding flaxseed flour. Meat Science. 82(4), 472-477. DOI: 10.1016/j.meatsci.2009.03.002.

Centers for Disease Control and Prevention (CDC) (2015). Surveillance for foodborne disease outbreaks, United States, 2013, annual report. Atlanta, Georgia: US Department of Health and Human Services.

Choi YS, Choi JH, Han DJ, Kim HY, Kim HW, Lee MA, Chung HJ, Kim CJ (2012). Effects of Laminaria japonica on the physico-chemical and sensory characteristics of reduced-fat pork patties. Meat Science. 91(1), 1-7. DOI: 10.1016/j.meatsci.2011.11.011.

Ciocan ID, Bara II (2007). Plant products as antimicrobial agents. analele stiintifice ale Universitatii 'Alexandru Loan Cuza', Sectiunea Genetica si Biologie Moleculara. TOM VIII, 151-5.

Contini, C, Álvarez R, O'sullivan M, Dowling DP, Gargan SÓ, Monahan FJ (2014). Effect of an active packaging with citrus extract on lipid oxidation and sensory quality of cooked turkey meat. Meat Science. 96(3), 1171-1176. DOI: 10.1016/j.meatsci.2013.11.007.

Cueva C, Moreno-Arribas MV, Bartolomé B, Salazar Ó, Vicente MF, Bills GF (2011). Antibiosis of vineyard ecosystem fungi against food-borne microorganisms. Research in Microbiology. 162(10), 1043-1051. DOI: 10.1016/j.resmic.2011.09.002. 
Çiçek Ü, Bulgan A (2013). Et ve et ürünlerinde heterosiklik aminler. Gaziosmanpaşa Üniversitesi Ziraat Fakültesi Dergisi. 2013(1). DOI: 10.1016/j.resmic.2011.09.002. DOI: 10.13002/jafag182.

Daglia M (2012). Polyphenols as antimicrobial agents. Current Opinion in Biotechnology. 23(2), 174-181. DOI: 10.1016/j.copbio.2011.08.007.

Dareddi MR, Angulalakudithi JB, Bandi E, Patrapalle SM, Sunkara V (2017). Comparative effect of rosemary extract, green tea extract and bha on microbiological quality of chicken meat sausages during refrigeration storage. International Journal of Livestock Research. 7(4), 250-255. DOI: 10.5455/ijlr.20170324030617.

Descalzo AM, Insani EM, Biolatto A, Sancho AM, Garcia PT, Pensel NA, Josifovich JA (2005). Influence of pasture or grain-based diets supplemented with vitamin E on antioxidant/oxidative balance of Argentine beef. Meat Science. 70(1), 35-44. DOI: 10.1016/j.meatsci.2004.11.018.

Dorman HJD, Peltoketo A, Hiltunen R, Tikkanen MJ (2003). Characterisation of the antioxidant properties of deodourised aqueous extracts from selected Lamiaceae herbs. Food Chemistry. 83(2), 255-262. DOI: 10.1016/S0308-8146(03)00088-8.

Ergezer H, Kaya HI, Şimşek Ö (2018). Antioxidant and antimicrobial potential of artichoke (cynara scolymus l.) extract in beef patties. Czech Journal of Food Sciences. 36(2), 154-162. DOI: 10.17221/179/2017-CJFS

Fernandez-Ginés JM, Fernández-López J, Sayas-Barberá E, Pérez-Alvarez J (2005). Meat products as functional foods: A review. Journal of Food Science. 70(2). DOI: 10.1111/j.1365-2621.2005.tb07110.x.

Fernandez-Lopez J, Zhi N, Aleson-Carbonell L, Perez-Alvarez JA, Kuri V (2005). Antioxidant and antibacterial activities of natural extracts: application in beef meatballs. Meat Science.69(3), 371-380. DOI: 10.1016/j.meatsci.2004.08.004.

García-Lomillo J, Del Pino-García R, Muñiz-Rodríguez P (2017a). Alternative natural seasoning to improve the microbial stability of low-salt beef patties. Food Chemistry. 227, 122-128. DOI: 10.1016/j.foodchem.2017.01.070.

Garcia-Lomillo J, Viegas O, Gonzalez-SanJose ML, Ferreira IM (2017b). Influence of red wine pomace seasoning and high-oxygen atmosphere storage on carcinogens formation in barbecued beef patties. Meat Science. 125, 10-15. DOI: 10.1016/j.meatsci.2016.11.009.

Gaulin C, Nguon S, Leblanc MA, Ramsay D, Roy S (2013). Multiple outbreaks of gastroenteritis that were associated with 16 funerals and a unique caterer and spanned 6 days, 2011, Quebec, Canada. Journal of Food Protection. 76(9), 1582-1589. DOI: 10.4315/0362-028X.JFP-13-079.

Georgantelis D, Blekas G, Katikou P, Ambrosiadis I, Fletouris DJ (2007). Effect of rosemary extract, chitosan and $\alpha$ tocopherol on lipid oxidation and colour stability during frozen storage of beef burgers. Meat Science. 75(2), 256-264. DOI: 10.1016/j.meatsci.2006.07.018.

Ghaderi-Ghahfarokhi M, Barzegar M, Sahari MA, Gavlighi HA, Gardini F (2017). Chitosan-cinnamon essential oil nanoformulation: Application as a novel additive for controlled release and shelf life extension of beef patties. International Journal of Biological Macromolecules. 102, 19-28. DOI: 10.1016/j.ijbiomac.2017.04.002.

Gibis M, Weiss J (2010). Inhibitory effect of marinades with hibiscus extract on formation of heterocyclic aromatic amines and sensory quality of fried beef patties. Meat Science. 85(4), 735-742. DOI: 10.1016/j.meatsci.2010.03.034.

Gök V, Bor Y (2012). Effect of olive leaf, blueberry and Zizyphus jujuba extracts on the quality and shelf life of meatball during storage. Journal of Food, Agriculture \& Environment. 10(2), 190-195.

Guran HS, Oksuztepe G, Coban OE, Incili GK (2015). Influence of different essential oils on refrigerated fish patties produced from bonito fish (Sarda sarda Bloch, 1793). Czech Journal of Food Science. 33(1). DOI: 10.17221/188/2014-CJFS.

Guyon C, Meynier A, De Lamballerie M (2016). Protein and lipid oxidation in meat: A review with emphasis on highpressure treatments. Trends in Food Science \& Technology. 50, 131-143. DOI: 10.1016/j.tifs.2016.01.026.

Hawashin MD, Al-Juhaimi F, Ahmed IAM, Ghafoor K, Babiker EE.(2016). Physicochemical, microbiological and sensory evaluation of beef patties incorporated with destoned olive cake powder. Meat Science. 122, 32-39. DOI: 10.1016/j.meatsci.2016.07.017.

Hygreeva D, Pandey MC, Radhakrishna K (2014). Potential applications of plant based derivatives as fat replacers, antioxidants and antimicrobials in fresh and processed meat products. Meat Science. 98(1), 47-57. DOI: 10.1016/j.meatsci.2014.04.006.

Ibrahim HM, Abou-Arab AA, Salem FMA (2011). Antioxidant and antimicrobial effect of some natural plant extracts added to lamb patties during storage. Grasas y Aceites. 62(2), 139-148. DOI: 10.3989/gya.066510.

International Agency Research on Cancer- IARC (1993). Monographs on the evaluation of carcinogenic risk to humans: Some naturally occurring aromatic amines and mycotoxins (Vol. 56, pp. 163-242). Lyon, France: International Agency for Research on Cancer (IARC).

International Agency for Research on Cancer- IARC (2015). monographs evaluate consumption of red meat and processed meat. International Agency for Research on Cancer and World Health Organisation, October 26, Lyon, France. 
International Agency for Research on Cancer (2017). GLOBOCAN 2012 v1. 0, Cancer incidence and mortality worldwide: IARC CancerBase No. 11. Lyon. Available via http://globocan. iarc. fr. Accessed, 6.

Janoszka B, Błaszczyk U, Damasiewicz-Bodzek A, Sajewicz M (2009). Analysis of heterocyclic amines (HAs) in panfried pork meat and its gravy by liquid chromatography with diode array detection. Food Chemistry. 113(4), 1188-1196.DOI: 10.1016/j.foodchem.2008.08.005.

Jayathilakan K, Sharma GK, Radhakrishna K, Bawa AS (2007). Antioxidant potential of synthetic and natural antioxidants and its effect on warmed-over-flavour in different species of meat. Food Chemistry. 105, 908-916. DOI: 10.1016/j.foodchem.2007.04.068.

Jiang J, Zhang X, True AD, Zhou L, Xiong YL (2013). Inhibition of lipid oxidation and rancidity in precooked pork patties by Radical-Scavenging licorice (Glycyrrhiza glabra) extract. Journal of Food Science. 78(11).DOI: 10.1111/1750-3841.12273.

Jimenez-Colmenero F, Carballo J, Cofrades S (2001). Healthier meat and meat products: their role as functional foods. Meat Science. 59(1), 5-13. DOI: 10.1016/S0309-1740(01)00053-5.

Jongberg S, Skov SH, Tørngren MA, Skibsted LH, Lund MN (2011). Effect of white grape extract and modified atmosphere packaging on lipid and protein oxidation in chill stored beef patties. Food Chemistry. 128(2), 276283. DOI: 10.1016/j.foodchem.2011.03.015.

Karre L, Lopez K, Getty KJ (2013). Natural antioxidants in meat and poultry products. Meat Science. 94(2), 220-227. DOI: 10.1016/j.meatsci.2013.01.007.

Keşkekoğlu H, Üren A (2014). Inhibitory effects of pomagranate seed extract on the formation of heterocyclic aromatic amines in beef and chicken meatballs after cooking by four different methods. Meat Science. 96, 1446-1451. DOI: 10.1016/j.meatsci.2013.12.004.

Kim SJ, Cho AR, Han J (2013). Antioxidant and antimicrobial activities of leafy green vegetable extracts and their applications to meat product preservation. Food Control. 29(1), 112-120. DOI: 10.1016/j.foodcont.2012.05.060.

Knize MG, Salmon CP, Mehta SS, Felton JS (1997). Analysis of cooked muscle meats for heterocyclic aromatic amine carcinogens. Mutation Research/Fundamental and Molecular Mechanisms of Mutagenesis. 376(1), 129-134. DOI: 10.1016/S0027-5107(97)00035-3.

Knize MG, Salmon CP, Pais P, Felton JS (1999). Food heating and the formation of heterocyclic aromatic amine and polycyclic aromatic hydrocarbon mutagens/carcinogens. In Impact of processing on food safety (pp. 179-193). Springer, Boston, MA. DOI: 0.1007/978-1-4615-4853-9_12.

Lai PK, Roy J (2004). Antimicrobial and chemopreventive properties of herbs and spices. Current medicinal chemistry. 11(11), 1451-1460. DOI: 10.2174/0929867043365107.

Lawrie RA, Ledward DA (2006). Lawrie's Meat Science. Seventh Edition (Woodhead Publishing in Food Science, Technology and Nutrition), England.

Longato E, Peiretti PG, Nurisso S, Meineri G (2017). Effects on composition, oxidative stability and fatty acid profile of meat of chickens fed diets containing animal fat or flax seed oil and supplemented with pumpkin seeds. In First International Conference" Babies and Animals: pediatrician meet vets (pp. 6-9). Veterinary Science.

Mariem C, Sameh M, Nadhem S, Soumaya Z, Najiba Z, Raoudha EG (2014). Antioxidant and antimicrobial properties of the extracts from Nitraria retusa fruits and their applications to meat product preservation. Industrial Crops and Products. 55, 295-303. DOI: 10.1016/j.indcrop.2014.01.036.

Milon M, Kabir MH, Hossain MA, Rahman M, Azad MAK, Hashem MA (2016). Value added beef meatballs using turmeric (Curcuma longa) powder as a source of natural antioxidant. Sciences. 3(4), 52-61.

Moroney NC, O'grady MN, O'doherty JV, Kerry JP (2013). Effect of a brown seaweed (Laminaria digitata) extract containing laminarin and fucoidan on the quality and shelf-life of fresh and cooked minced pork patties. Meat science, 94(3), 304-311. DOI: 10.1016/j.meats. .ci.2013.02.010.

Morsy MK., Mekawi E, Elsabagh R (2018). Impact of pomegranate peel nanoparticles on quality attributes of meatballs during refrigerated storage. LWT, 89, 489-495. DOI: 10.1016/j.lwt.2017.11.022.

Munekata PES, Fernandes RDPP, de Melo MP, Trindade MA, Lorenzo JM (2016). Influence of peanut skin extract on shelf-life of sheep patties. Asian Pacific Journal of Tropical Biomedicine. 6(7), 586-596. DOI: 10.1016/j.apjtb.2016.05.002.

Murkovic M, Steinberger D, Pfannhauser W (1998). Antioxidant spices reduce the formation of heterocyclic amines in fried meat. Zeitschrift für Lebensmitteluntersuchung und-Forschung A. 207(6), 477-480. DOI: 10.1007/s002170050364.

Naveena BM, Sen AR, Vaithiyanathan S, Babji Y, Kondaiah N (2008). Comparative efficacy of pomegranate juice, pomegranate rind powder extract and BHT as antioxidants in cooked chicken patties. Meat Science. 80, 304-308. DOI: 10.1016/j.meatsci.2008.06.005. 
Nunez de Gonzalez MT, Boleman RM, Miller RK, Keeton JT, Rhee KS (2008). Antioxidant properties of dried plum ingredients in raw and precooked pork sausage. Journal of Food Science. 73(5). DOI: 10.1111/j.17503841.2008.00744.x.

Oussalah M, Caillet S, Saucier L, Lacroix M (2007). Inhibitory effects of selected plant essential oils on the growth of four pathogenic bacteria: E. coli O157: H7, Salmonella typhimurium, Staphylococcus aureus and Listeria monocytogenes. Food Control. 18(5), 414-420. DOI: 10.1016/j.foodcont.2005.11.009.

Oz F (2014). Effects of water extract of Urtica dioica L. on the quality of meatballs. Journal of food processing and preservation. 38(3), 1356-1363. DOI: 10.1111/jfpp.12097.

Oz F, K1z1l M (2013). Determination of heterocyclic aromatic amines in cooked commercial frozen meat products by ultrafast liquid chromatography. Food Analytical Methods. 6(5), 1370-1378. DOI: 10.1007/s12161-012-9553-9

Oz F, Kaya M (2011). The inhibitory effect of blackpepper on formation of heterocyclicaromaticamines in highfatmeatball. Food Control. 22(3), 596-600. DOI: 10.1016/j.foodcont.2010.10.010.

Oz F (2014). Effects of water extract of Urtica dioica L. on the quality of meatballs. Journal of Food Processing and Preservation. 38(3), 1356-1363.

Özdemir H, Soyer A, Tağı Ş, Turan M (2014). Nar kabuğu ekstraktının antimikrobiyel ve antioksidan aktivitesinin köfte kalitesine etkisi. G1da/The Journal of Food. 39(6). DOI: 10.15237/gida.GD14052.

Özen F, Çoșkun F (2014). Effect of herbal extracts addition on microbial composition and sensory properties of Tekirdag meatballs. Journal of Tekirdag Agricultural Faculty. 11(3), 100-109.

Öztan A. (1993). Et Bilimi ve Teknolojisi. Hacettepe Üniversitesi Mühendislik Fakültesi Yayınları. 277, Ankara.

Öztürk A, Yilmaz N ve Güneş G (2010). Effect of different modified atmosphere packaging on microbial quality, oxidation and colour of a seasoned ground beef product (Meatball). Packaging Technology and Science. 23, 19-25. DOI: 10.1002/pts.875.

Palmieri B, Sblendorio V (2007). Oxidative stress tests: overview on reliability and use. European review for medical and pharmacological sciences. 11(6), 383-399.

Persson E, Graziani G, Ferracane R, Fogliano V, Skog K (2003). Influence of antioxidants in virgin olive oil on the formation of heterocyclic amines in fried beefburgers. Food and Chemical Toxicology. 41(11), 1587-1597. DOI: 10.1016/S0278-6915(03)00190-X.

Puangsombat K, Gadgil P, Houser T, Hunt M and Smith S (2011). Heterocyclic amine content in commercial ready to eat meat products. Meat Science. 88: 227-233. DOI: 10.1016/j.meatsci.2010.12.025.

Quelhas I, Petisca C, Viegas O, Melo A, Pinho O, Ferreira IMPLVO (2010). Effect of green tea marinades on the formation of heterocyclic aromatic amines and sensory quality of pan-fried beef. Food Chemistry. 122(1), 98-104. DOI: 10.1016/j.foodchem.2010.02.022.

Reddy DM, Vani S, Naveen Z, Rao BE (2017). Comparative effect of natural and synthetic anioxidants on microbiological quality of chicken meat patties during refrigeration storage. International Journal of Science, Environment and Technology. 6(1), 443-448.

Rodríguez-Carpena JG, Morcuende D, Andrade MJ, Kylli P, Estévez M (2011). Avocado (Persea americana Mill.) phenolics, in vitro antioxidant and antimicrobial activities, and inhibition of lipid and protein oxidation in porcine patties. Journal of Agricultural and Food Chemistry. 59(10), 5625-5635. DOI: 10.1021/jf1048832.

Rounds L, Havens CM, Feinstein Y, Friedman M, Ravishankar S (2013). Concentration-dependent inhibition of Escherichia coli O157: H7 and heterocyclic amines in heated ground beef patties by apple and olive extracts, onion powder and clove bud oil. Meat Science. 94(4), 461-467. DOI: 10.1016/j.meatsci.2013.03.010.

Sengun IY, Yildiz Turp G, Kilic G, Sucu C (2018). Effectiveness of Corduk (Echinophora tenuifolia subsp. sibthorpiana) on safety and quality of kofte, a Turkish style meatball. Journal of Food Safety. 38(1), e12389.

Shah MA, Bosco SJD, Mir SA (2014). Plant extracts as natural antioxidants in meat and meat products. Meat Science. 98(1), 21-33. DOI: 10.1016/j.meatsci.2014.03.020.

Tajik H, Farhangfar A, Moradi M, Razavi Rohani SM (2014). Effectiveness of clove essential oil and grape seed extract combination on microbial and lipid oxidation characteristics of raw buffalo patty during storage at abuse refrigeration temperature. Journal of Food Processing and Preservation. 38(1), 31-38.

Turgut SS, Soyer A, Işıkçı F (2016). Effect of pomegranate peel extract on lipid and protein oxidation in beef meatballs during refrigerated storage. Meat Science. 116, 126-132. DOI: 10.1016/j.meatsci.2016.02.011.

Verma AK, Pathak V, Singh VP, Umaraw P (2016). Storage study of chicken meatballs incorporated with green cabbage (Brassica olerecea) at refrigeration temperature $(4 \pm 1 \mathrm{C})$ under aerobic packaging. Journal of Applied Animal Research. 44(1), 409-414. DOI: 10.1080/09712119.2015.1091328.

Villalobos-Delgado LH, Caro I, Blanco C, Bodas R, Andrés S, Giráldez FJ, Mateo J (2015). Effect of the addition of hop (infusion or powder) on the oxidative stability of lean lamb patties during storage. Small Ruminant Research. 125, 73-80. DOI: 10.1016/j.smallrumres.2015.02.008. 
Vitaglione P, Fogliano V (2004). Use of antioxidants to minimize the human health risk associated to mutagenic/carcinogenic heterocyclic amines in food. Journal of Chromatography B. 802(1), 189-199. DOI: 10.1016/j.jchromb.2003.09.029.

Yildiz-Turp G, Serdaroglu M (2010). Effects of using plum puree on some properties of low fat beef patties. Meat Science. 86(4), 896-900. DOI: 10.1016/j.meatsci.2010.07.009.

Zhou GH, Xu XL, Liu Y (2010). Preservation technologies for fresh meat-A review. Meat Science. 86(1), 119-128. DOI: 10.1016/j.meatsci.2010.04.033. 